\title{
Energy efficient thermal insulation materials for external building walls
}

\author{
Muzarib Bzhakhov, Shamil Battaev*, and Malika Nastuyeva \\ Kabardino-Balkarian State University named after Kh.M. Berbekov, 360004, Nalchik, Russia
}

\begin{abstract}
This article discusses various types of energy efficient thermal insulation materials. The energy efficiency calculation of a multi-storey 36-apartment residential building using various options for the insulation of enclosing structures has been carried out, after which the results have been compared.
\end{abstract}

\section{Introduction}

Energy conservation is one of the priority tasks of the state at present. This is due to the shortage of basic energy resources, the increasing cost of their extraction, as well as to global environmental problems. It is known that most of the energy resources in the country are produced from fossil fuels $(90 \%)[1,6,9,11]$.

The building should be designed and erected in such a way that, while meeting the established requirements for the internal microclimate of the premises and other living conditions, to ensure the efficient and economic use of energy resources during its operation [2]. However, any energy-saving measure requires the expenditure of funds necessary for its implementation. So how can it be possible to efficiently use energy and improve the energy efficiency of a residential building? For example, the use of effective insulation in the structures of external walls, technical floors, roofs, ceilings above the basement can reduce heat loss by up to $40 \%$ [3].

Let us consider this statement using the example of calculating the energy efficiency of a multi-storey 36-apartment residential building located at: KBR, Nalchik, Tarchokova str. The capital construction facility is located in III B climatic subarea. The adopted design solutions pursue the goal of building a residential building using energy resources while ensuring comfortable conditions for the people to stay in it, by increasing the heat-shielding properties of the building, energy-efficient engineering support systems using modern equipment, control valves and devices for energy costs accounting and regulation (electricity, hot and cold water).

Design conditions. Climatic data.

Design indoor air temperature $t_{\text {int }}=20^{\circ} \mathrm{C}$.

Estimated outside air temperature for the city of Nalchik $t_{e x t}=-18^{\circ} \mathrm{C}$.

Heating period duration $z_{h t}=168$ days.

\footnotetext{
* Corresponding author: battaev15@gmail.com
} 
Average outdoor temperature for the heating period for the city Nalchik $t_{e x t}^{a v}=0.6^{\circ} \mathrm{C}$.

Degree-day of the heating period $D_{d}$ is calculated by the formula:

$$
D_{d}=\left(t_{\text {int }}-t_{e x t}^{a v}\right) \cdot z_{h t}=(20-(+0.6)) \cdot 168=3259^{\circ} \mathrm{C} \cdot \text { days }
$$

\section{Thermal performance}

Reduced resistance to external fences heat transfer $R_{0}^{r}, m^{2} \cdot{ }^{\circ} \mathrm{C} / \mathrm{W}$ are not lower than the required values $R_{0}^{r}$, which are installed by BC 131.13330.2018 depending on the degreeday of the heating period. For $D_{d}=3259^{\circ} \mathrm{C} \cdot$ days the required resistance to heat transfer is equal to :

- walls $R_{W}^{\text {red }}=2.80 \mathrm{~m}^{2} \cdot{ }^{\circ} \mathrm{C} / \mathrm{W}$;

- windows $R_{f}^{\text {red }}=0.45 \mathrm{~m}^{2} \cdot{ }^{\circ} \mathrm{C} / \mathrm{W}$;

- coverings $R_{c}^{r e d}=4.2 m^{2} \cdot{ }^{\circ} \mathrm{C} / \mathrm{W}$;

- stained glass $R_{f}^{\text {red }}=0.45 \mathrm{~m}^{2} \cdot{ }^{\circ} \mathrm{C} / \mathrm{W}$;

- lanterns $R_{c}^{\text {red }}=0.35 \mathrm{~m}^{2} \cdot{ }^{\circ} \mathrm{C} / \mathrm{W}$;

- doors and gates $R_{e d}^{r e d}=0.35 m^{2} \cdot{ }^{\circ} \mathrm{C} / \mathrm{W} ;[4]$

Space-planning parameters

The total area of the external enclosing structures of the building $A_{e}$.

The area of the walls, including windows, evacuation and entrance doors to the building, stained glass,

$$
A_{w}=A_{W+F+e d}=1902.66+348.1+659.04+3.8=2913.6 \mathrm{~m}^{2},
$$

Exterior wall area $\mathrm{AW}, \mathrm{M}^{2}$, is determined by the formula

$$
A_{W}=A_{W+F+e d}-A_{F}-A_{e d}=2913.6-348.1-659.04-3.8 \mathrm{~m}^{2}
$$

Total area of external enclosing structures $A_{e}$ is determined by the formula:

$$
A_{e}^{\text {sum }}=A_{W+F+e d}+A_{c}+A_{f}+A_{r}=2913.6+484.87+3264.9=6663.37 \mathrm{~m}^{2},
$$

Heated area (total area) $A_{h}=4632.41 \mathrm{~m}^{2}$, and calculated area $A_{r}=3264.9 \mathrm{~m}^{2}$.

Heated building volume

$$
V_{h}=A_{s t} \cdot H_{h}=15286.95 \mathrm{~m}^{3}
$$

Glazing coefficient of building facades

$$
p=A_{F} / A_{W+F+e d}=1007.14 / 2913.6=0.345
$$

Building compactness index

$$
k_{e}^{\text {des }}=A_{e}^{\text {sum }} / V_{h}=6663.37 / 15286.95=0.43
$$

Resistance calculation of the building structures' heat transfer 
Walls:

Let us consider several options for the outer wall design:

Option 1 - A wall made of gas silicate blocks without effective insulation (Fig. 1):

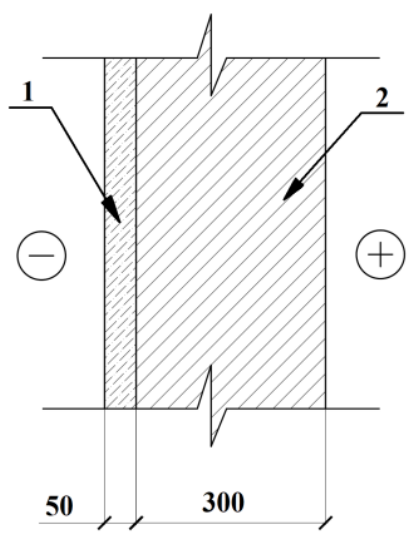

Fig. 1. Construction of an external wall without effective insulation

1. Gas silicate blocks, $\delta-300 \mathrm{~mm} ., \lambda=0.12 \mathrm{~W} / \mathrm{m}^{2} \cdot{ }^{\circ} \mathrm{C}, \gamma=500 \mathrm{~kg} / \mathrm{m}^{3}$.

2. Cement-sand plaster $\delta-50 \mathrm{~mm}$. $\lambda=0.58 \mathrm{~W} / \mathrm{m}^{2} \cdot{ }^{\circ} \mathrm{C}, \gamma=1800 \mathrm{~kg} / \mathrm{m}^{3}$.

The calculated reduced heat transfer resistance of the structure will be:

$$
R_{W}=\frac{1}{8.7}+\frac{0.05}{0.58}+\frac{0.3}{0.10}+\frac{1}{23}=3.22 \mathrm{~m}^{2} \cdot{ }^{\circ} \mathrm{C} / \mathrm{W}
$$

Taking into account the uniformity coefficient, the calculated resistance to heat transfer will be equal to:

$$
R_{W}^{r}=3.22 \cdot 0.9=2.9 m^{2} \cdot{ }^{\circ} \mathrm{C} / \mathrm{W}
$$

Condition satisfied.

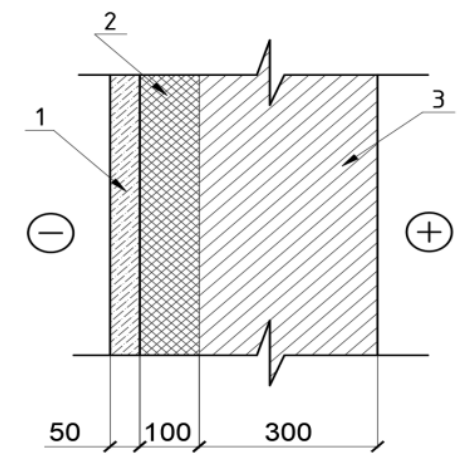

Fig. 2. Construction of an external wall with insulation «ROCKWOOL»

Option 2 - Wall made of gas silicate blocks with basalt wool («ROCKWOOL FACADE Optima») as a heater (Fig.2): 
Gas silicate blocks, $\delta-300 \mathrm{~mm} ., \lambda=0.12 \mathrm{~W} / \mathrm{m}^{2} \cdot{ }^{\circ} \mathrm{C}, \quad \gamma=500 \mathrm{~kg} / \mathrm{m}^{3}$. Insulation «FACADE Optima», $\delta-100 \mathrm{~mm} ., \lambda=0.042 \mathrm{~W} / \mathrm{m}^{2} \cdot{ }^{\circ} \mathrm{C}, \gamma=145 \mathrm{~kg} / \mathrm{m}^{3} \cdot$.[10] Cement-sand plaster $\delta$ - $50 \mathrm{~mm} . \lambda=0.58 \mathrm{~W} / \mathrm{m}^{2} \cdot{ }^{\circ} \mathrm{C}, \gamma=1800 \mathrm{~kg} / \mathrm{m}^{3}$.

The calculated reduced heat transfer resistance of the structure will be:

$$
R_{W}=\frac{1}{8.7}+\frac{0.05}{0.58}+\frac{0.1}{0.042}+\frac{0.3}{0.10}+\frac{1}{23}=5.62 \mathrm{~m}^{2} \cdot{ }^{\circ} \mathrm{C} / \mathrm{W}
$$

Taking into account the uniformity coefficient, the calculated resistance to heat transfer will be equal to:

Condition satisfied.

$$
R_{W}^{r}=5.62 \cdot 0.9=5.05 m^{2} \cdot{ }^{\circ} \mathrm{C} / W
$$

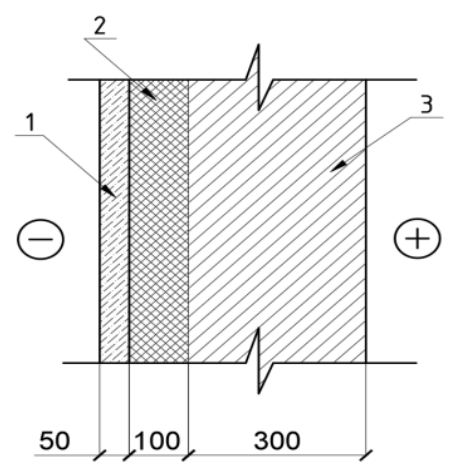

Fig. 3. Construction of an external wall with insulation «PIR slab»

Option 3 - A wall made of gas silicate blocks with expanded polyisocyanurate ("PIR slab") as insulation (Fig. 3):

Gas silicate blocks, $\delta$ - $300 \mathrm{~mm} ., \lambda=0.12 \mathrm{~W} / \mathrm{m}^{2} \cdot{ }^{\circ} \mathrm{C}, \gamma=500 \mathrm{~kg} / \mathrm{m}^{3}$.

Thermal insulation «PIR slab», $\delta-100 \mathrm{~mm} ., \lambda=0.023 \mathrm{~W} / \mathrm{m}^{2} \cdot{ }^{\circ} \mathrm{C}, \gamma=50 \mathrm{~kg} / \mathrm{m}^{3}$.

Cement-sand plaster $\delta-50 \mathrm{~mm} . \lambda=0.58 \mathrm{~W} / \mathrm{m}^{2} \cdot{ }^{\circ} \mathrm{C}, \gamma=1800 \mathrm{~kg} / \mathrm{m}^{3}$.

The calculated reduced heat transfer resistance of the structure will be:

$$
R_{W}=\frac{1}{8.7}+\frac{0.05}{0.58}+\frac{0.1}{0.023}+\frac{0.3}{0.10}+\frac{1}{23}=7.59 \mathrm{~m}^{2} \cdot{ }^{\circ} \mathrm{C} / \mathrm{W}
$$

Taking into account the uniformity coefficient, the calculated resistance to heat transfer will be equal to:

Condition satisfied.

$$
R_{W}^{r}=7.59 \cdot 0.9=6.8 m^{2} \cdot{ }^{\circ} \mathrm{C} / \mathrm{W}
$$




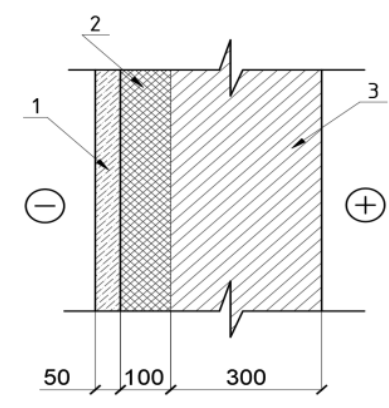

Fig. 4. Construction of an external wall with insulation «Penoplex»

Option 4 - Wall made of gas silicate blocks with extruded polystyrene foam («Penoplex») as insulation (Fig. 3):

External walls - gas silicate blocks, $\delta-300 \mathrm{~mm} ., \lambda=0.12 \mathrm{~W} / \mathrm{m}^{2} \cdot{ }^{\circ} \mathrm{C}, \gamma=500 \mathrm{~kg} / \mathrm{m}^{3}$.

Insulation «Penoplex», $\delta-100 \mathrm{~mm} ., \lambda=0.03 \mathrm{~W} / \mathrm{m}^{2} \cdot{ }^{\circ} \mathrm{C}, \gamma=40 \mathrm{~kg} / \mathrm{m}^{3}$.

3. Cement-sand plaster $\delta-50 \mathrm{~mm} . \lambda=0.58 \mathrm{~W} / \mathrm{m}^{2} \cdot{ }^{\circ} \mathrm{C}, \gamma=1800 \mathrm{~kg} / \mathrm{m}^{3}$.

The calculated reduced heat transfer resistance of the structure will be:

$$
R_{W}=\frac{1}{8.7}+\frac{0.05}{0.58}+\frac{0.1}{0.03}+\frac{0.3}{0.10}+\frac{1}{23}=6.5 \mathrm{~m}^{2} \cdot{ }^{\circ} \mathrm{C} / \mathrm{W}
$$

Taking into account the uniformity coefficient, the calculated resistance to heat transfer will be equal to:

$$
R_{W}^{r}=6.5 \cdot 0.9=5.85 m^{2} \cdot{ }^{\circ} \mathrm{C} / \mathrm{W}
$$

Condition satisfied.

Coverage (on reinforced concrete slabs):

- Cement strainer - $30 \mathrm{~mm}, \lambda=0.58 \mathrm{~W} / \mathrm{m}^{2} \cdot{ }^{\circ} \mathrm{C}, \gamma=1800 \mathrm{~kg} / \mathrm{m}^{3}$.

- Insulation, urea formaldehyde foam insulation, - $250 \mathrm{~mm} \lambda=0.037 \mathrm{~W} / \mathrm{m}^{2} \cdot{ }^{\circ} \mathrm{C}$, $\gamma=40 \mathrm{~kg} / \mathrm{m}^{3}$

- 1 layer of roofing material on bituminous mastic;

- Concrete $-200 \mathrm{~mm}, \lambda=2.04 \mathrm{~W} / \mathrm{m}^{2} \cdot{ }^{\circ} \mathrm{C}, \gamma=2500 \mathrm{~kg} / \mathrm{m}^{3}$

The calculated reduced heat transfer resistance of the structure will be:

$$
R_{W}=\frac{1}{8.7}+\frac{0.03}{0.58}+\frac{0.25}{0.037}+\frac{0.20}{2.04}+\frac{1}{23}=7.05 \mathrm{~m}^{2} \cdot{ }^{\circ} \mathrm{C} / \mathrm{W}
$$

Taking into account the uniformity coefficient $(0.75)$, the calculated resistance to heat transfer will be equal to:

$$
R_{W}=7,05 \cdot 0,75=5,28 m^{2} \cdot{ }^{\circ} \mathrm{C} / \mathrm{W}
$$

Condition satisfied.

Windows:

Window blocks are taken from PVC profiles with a single-chamber double-glazed window 4M1 - 16Ar - 4M1, GOST 30674-99. According to the manufacturer's technical test report: 


$$
R_{F 1}^{r}=0.59 m^{2} \cdot{ }^{\circ} \mathrm{C} / \mathrm{W}
$$

Condition satisfied.

Doors:

Door blocks are adopted in a metal profile filled with foam. According to the manufacturer's technical test report:

$$
R_{F 1}^{r}=0.56 m^{2} \cdot{ }^{\circ} \mathrm{C} / \mathrm{W}
$$

Condition satisfied.

Floors:

Ground contact floors $\left(A_{f}, m^{2}=1880.27\right)$, divided into the zones $2.0 \mathrm{~m}$ wide from the outer walls of the building in contact with the ground.

Only 1 living zone is insulated, which is considered to be 2.0 meters wide from the inner surface of the outer wall along the perimeter of the building, the rest of the zones are taken without insulation. The areas of the zones and their resistance to heat transfer are shown in Table 1:

Table 1. Zones' areas and their resistance to heat transfer

\begin{tabular}{|c|c|c|}
\hline & $A_{f}, m^{2}$ & $R_{i}, m^{2} \cdot{ }^{\circ} \mathrm{C} / \mathrm{W}$ \\
\hline Zone I & 175 & 2.1 \\
\hline Zone II & 142 & 4.3 \\
\hline Zone III & 108 & 8.6 \\
\hline
\end{tabular}

Reduced resistance to heat transfer of fences along the ground:

$$
R_{f}=3264 /(175 / 2.1+142 / 4.3+108 / 8.6)=25.30 m^{2} \cdot{ }^{\circ} \mathrm{C} / \mathrm{W}
$$

\section{Reduced transmission heat transfer coefficient}

Let us calculate the reduced transmission coefficient of the building heat transfer $K_{m}^{t r}, m^{2} \cdot{ }^{\circ} \mathrm{C} / \mathrm{W}$ for various options for insulating the walls of the building according to the formula:

$$
K_{m}^{t r}=\beta\left(A_{W} / R_{W}^{r}+A_{F 1} / R_{F 1}^{r}+A_{r} / R_{r}^{r}+n A_{C 1} / R_{C 1}^{r}+n A_{f} / R_{f}^{r}\right) / A_{e}^{\text {sum }}
$$

Option $1 K_{m}^{t r}=1.1(1902.66 / 2.9+1007 / 0.59+3264 / 5.28+4632 / 25.3) / 6663.37=0.52 \mathrm{~W} / \mathrm{m}^{2} \cdot{ }^{\circ} \mathrm{C}$ Option $2 K_{m}^{t r}=1.1(1902.66 / 5.05+1007 / 0.59+3264 / 5.28+4632 / 25.3) / 6663.37=0.43 \mathrm{~W} / \mathrm{m}^{2} \cdot{ }^{\circ} \mathrm{C}$ Option $3 K_{m}^{t r}=1.1(1902.66 / 6.8+1007 / 0.59+3264 / 5.28+4632 / 25.3) / 6663.37=0.41 \mathrm{~W} / \mathrm{m}^{2} \cdot{ }^{\circ} \mathrm{C}$ Option $4 K_{m}^{t r}=1.1(1902.66 / 5.85+1007 / 0.59+3264 / 5.28+4632 / 25.3) / 6663.37=0.42 \mathrm{~W} / \mathrm{m}^{2} \cdot{ }^{\circ} \mathrm{C}$ Reduced infiltration (conditional) heat transfer coefficient of the building $K_{\text {inf }}, W /\left(m^{2} \cdot{ }^{\circ} \mathrm{C}\right)$, is determined by the formula:[5]

$$
K_{\mathrm{inf}}=0.28 \cdot c \cdot n \cdot \beta_{v} \cdot V_{h} \cdot k / A_{e}^{\text {sum }}, W /\left(m^{2} \cdot{ }^{\circ} \mathrm{C}\right),
$$


$c$ - specific heat capacity of air, equal to $1 \mathrm{~kJ} /\left(\mathrm{kg} \cdot{ }^{\circ} \mathrm{C}\right)$;

$n_{a}$ - average air exchange rate equal to $1.81 \mathrm{~h}-1$;

$\beta_{v}$ - volume reduction factor, 0.85 ;

$\mathrm{V}_{h}$ - heated building volume, $\mathrm{m}^{3}$;

$\gamma_{a}^{h t}$ - average density of outdoor air during the heating period, $\mathrm{kg} / \mathrm{m}^{3}$;

$k$ - the coefficient of accounting for the influence of the counter heat molasses in the structure equal to 1 ;

$A_{e}^{\text {sum }}$ - the sum of the guard rails.

$$
K_{\mathrm{inf}}=0.28 \cdot 1 \cdot 1.81 \cdot 0.85 \cdot 15286 \cdot 1.28 \cdot 1 / 6663.37=1.26 \mathrm{~W} /\left(\mathrm{m}^{2} \cdot{ }^{\circ} \mathrm{C}\right)
$$

\section{Total heat transfer coefficient of the building}

Total heat transfer coefficient of the building $K_{m}, W /\left(m^{2} \cdot{ }^{\circ} \mathrm{C}\right)$, is determined by the formula $K_{m}=K_{m}^{i r}+K_{m}^{\text {inf }}, W /\left(m^{2} \cdot{ }^{\circ} \mathrm{C}\right)$ for each option of building walls insulation:

Option 1: $K_{m}=0.52+1.26=1.78 \mathrm{~W} /\left(\mathrm{m}^{2} \cdot{ }^{\circ} \mathrm{C}\right)$.

Option 2: $K_{m}=0.43+1.26=1.69 \mathrm{~W} /\left(m^{2} \cdot{ }^{\circ} \mathrm{C}\right)$.

Option 3: $K_{m}=0.41+1.26=1.67 \mathrm{~W} /\left(m^{2} \cdot{ }^{\circ} \mathrm{C}\right)$.

Option 4: $K_{m}=0.42+1.26=1.68 \mathrm{~W} /\left(m^{2} \cdot{ }^{\circ} \mathrm{C}\right)$.

\section{Heat and power indicators}

Total heat loss through the envelope of the building during the heating period $Q_{h}$, MJ is determined by the formula for each option for insulating the walls of the building:

$$
Q_{h}=0.0864 \cdot \mathrm{K}_{m} \cdot D_{d} \cdot A_{e}^{\text {sum }}
$$

Option №1: $Q_{h}=0.0864 \cdot 1.78 \cdot 3259 \cdot 6663=3339549$ MJ;

Option №2: $Q_{h}=0.0864 \cdot 1.69 \cdot 3259 \cdot 6663=3170696 \mathrm{MJ}$;

Option №3: $Q_{h}=0.0864 \cdot 1.67 \cdot 3259 \cdot 6663=3133173 \mathrm{MJ}$;

Option №4: $Q_{h}=0.0864 \cdot 1.68 \cdot 3259 \cdot 6663=3151934$ MJ.

Demand for heat energy for heating the building during the heating period $Q_{h}^{y}$, MJ can be determined by the formula:

$$
Q_{h}^{y}=\left[Q_{h}-\left(Q_{\text {int }}+Q_{s}\right) v\right] \beta_{h}
$$

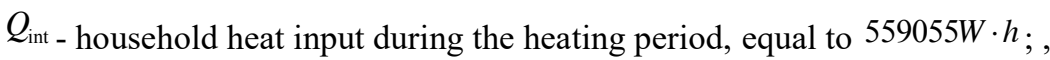

$Q_{s_{\text {s }}}$ heat gain through the windows from solar radiation during the heating period is equal to - $390727 \mathrm{MJ}$;

$v=0.8$ - coefficient that takes into account the ability of the building envelope to accumulate or release heat;

$\beta_{h}=1.11$ - coefficient taking into account additional heat consumption; 
We will perform the calculation for each variant of the building envelope insulation:

Option $1-Q_{h}^{y}=[3339549-(559055+390727) \times 0.8] \times 1.11=2863492 \mathrm{MJ}$;

Option $2-Q_{h}^{y}=[3170696-(559055+390727) \times 0.8] \times 1.11=2676066 \mathrm{MJ}$;

Option $3-Q_{h}^{y}=[3133173-(559055+390727) \times 0.8] \times 1.11=2634415 \mathrm{MJ}$;

Option $4-Q_{h}^{y}=[3339549-(559055+390727) \times 0.8] \times 1.11=2655240 \mathrm{MJ}$;

Specific consumption of heat energy for heating the building

$q_{h}^{\text {des }}$ denotes the estimated specific consumption of heat energy for heating the building, $\left[\mathrm{kJ} /\left(\mathrm{m}^{3} \cdot{ }^{\circ} \mathrm{C}\right.\right.$ days $\left.)\right]$, which is determined by the formula: $\left[q_{h}^{\text {des }}=10^{3} Q_{h} /\left(V_{h} \cdot D_{d}\right)\right]$ for each variant of insulation of the building outer walls:

Option $1-q_{h}^{\text {des }}=10^{3}\left[2863492 /(15286.95 \cdot 3259)=57.4 \mathrm{~kJ} /\left(\mathrm{m}^{3} \cdot{ }^{\circ} \mathrm{C}\right.\right.$ days $\left.)\right]$.

Option $2-q_{h}^{\text {des }}=10^{3}\left[2676066 /(15286.95 \cdot 3259)=53.7 \mathrm{~kJ} /\left(\mathrm{m}^{3} \bullet{ }^{\circ} \mathrm{C}\right.\right.$ days $\left.)\right]$

Option $3-q_{h}^{\text {des }}=10^{3}\left[2633492 /(15286.95 \cdot 3259)=52.8 \mathrm{~kJ} /\left(\mathrm{m}^{3} \cdot{ }^{\circ} \mathrm{C}\right.\right.$ days $\left.)\right]$

Option $4-q_{h}^{\text {des }}=10^{3}\left[2655240 /(15286.95 \cdot 3259)=53.2 \mathrm{~kJ} /\left(\mathrm{m}^{3} \cdot{ }^{\circ} \mathrm{C}\right.\right.$ days $\left.)\right]$.

The energy efficiency coefficient of the heat supply system from a heat source $\eta_{0}=0.8$.

Specific consumption of thermal energy by the heat supply system for heating a building from a heat source $q_{e}, \mathrm{~kJ} /\left(\mathrm{m}^{3} \bullet{ }^{\circ} \mathrm{C}\right.$ days $)$ can be determined by the formula for each option for insulation of the outer walls of the building:

$$
q_{e}=q_{h}^{\text {des }} / \eta_{0}^{\text {des }}
$$

Option $1-q_{e}=57.4 / 0.8=71.75 \mathrm{~kJ} /\left(\mathrm{m}^{3} \cdot{ }^{\circ} \mathrm{C}\right.$ days $)$;

Option $2-q_{e}=53.7 / 0.8=67.13 \mathrm{~kJ} /\left(\mathrm{m}^{3} \cdot{ }^{\circ} \mathrm{C}\right.$ days $)$;

Option $3-q_{e}=52.8 / 0.8=66 \mathrm{~kJ} /\left(\mathrm{m}^{3} \cdot{ }^{\circ} \mathrm{C}\right.$ days $)$;

Option $4-q_{e}=53.2 / 0.8=66.5 \mathrm{~kJ} /\left(\mathrm{m}^{3} \cdot{ }^{\circ} \mathrm{C}\right.$ days $)$;

Comparison of the calculation results is presented in Figure 5:

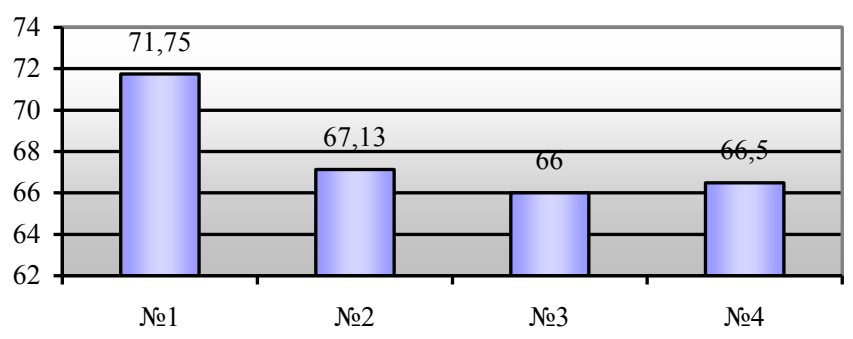

Fig. 5. Specific consumption of thermal energy by the heat supply system for heating a building from a heat source $q_{e}, \mathrm{~kJ} /\left(\mathrm{m}^{3} \cdot{ }^{\circ} \mathrm{C}\right.$ days $)$ with various options for the building envelope insulation 


\section{Conclusion}

In conclusion, it is possible to assume that the most energy-efficient variant of external enclosing structures insulation with the same thickness of the above-mentioned is option No. 3 - a wall of gas silicate blocks using a PIR-slab as an effective insulation.

Energy efficiency is not a mere formality. The taken and justified measures will help to reduce thermal energy consumption for heating the building and, consequently, save a large amount of material resources by reducing heat losses.

Globally, if energy efficiency requirements are met, the efficiency of non-renewable resources use increases, which has a beneficial effect on the ecological situation of the territory, region and country.

\section{References}

1. V.K. Averyanov, L.A. Podolyan, A.I. Tyutyunnikov, R.Yu. Zaretsky, Heat and energy efficient technologies 3, (2002)

2. Federal Law of November 23, 2009 No. 261-FL "On Energy Saving and on Increasing Energy Efficiency and on Amendments to Certain Legislative Acts of the Russian Federation" (as amended on July 26, 2019).

3. M.V. Popova, T.N. Yashkova, Methods for improving the energy efficiency of buildings (Vladimir, 2014)

4. BC 131.13330.2018 «Building climatology»

5. BC 50.13330.2012 «Thermal protection of buildings»

6. N.A. Strakhova, P.A. Lebedinsky, Engineering Journal of Don 3, (2012)

7. V.N. Bogoslovsky, Thermal regime of the building (Stroyizdat, Moscow, 1979)

8. T.S. Rogers, Designing thermal protection of buildings. Translated from English (Stroyizdat, Moscow, 1966)

9. A.I. Kruglova, Climate and enclosing structures (Gosstroyizdat, Moscow, 1970)

10. ROCWOOL «FACADE SYSTEM». Album of technical solutions (ROCWOOL, Moscow, 2011)

11. Yu. P. Gamburg, Accounting for heat introduced by solar radiation (Gosstroyizdat, Moscow, 1966)

12. A. Rosemann, H. Kaase, Solar Energy 78, 772-780 (2005) 